https://doi.org/10.52058/2708-7530-2021-12(18)-406-422

Кухарчук Наталія Петрівна аспірантка кафедри авіаційної психології, Національного авіаційного університету, 03058, Україна, м Київ, просп. Космонавта Комарова, 1, e-mail: nata.organicera@gmail.com, https://orcid.org/0000-0003-4992-0433

\title{
ВПЛИВ ТРАДИЦЙ, ЯК СОЦІАЛЬНОГО ЧИННИКА НА СТАВЛЕННЯ ДО ОДРУЖЕННЯ У ЖІНОК У ПЕРІОД РАННЬОЇ ДОРОСЛОСТІ
}

Анотація. Публікація актуалізує як вплив сучасних тенденцій буденності змінює традиційні погляди та відношення до багаторічних традицій стосовно одруження, подружнього життя та сімейно-шлюбних відносин і як такі зміни впливають на формування поведінки та поглядів жінок раннього віку дорослості на одруження в умовах сучасності.

Сім'я це спільнота людей, що пов'язані між собою взаємними правами і обов'язками як подружжя, як батьків чи майбутніх батьків, веденням спільного господарства, спільними поглядами або об'єднані однією метою щодо шляхів розвитку своєї створеної сім'ї. Вона створена та існує як первинний осередок суспільства, наділена важливими соціальними функціями, має могутні традиції, і займає істотне місце в житті кожної людини. Це соціальна інституція і наразі, вона залишається найбільш стійкою в соціальній структурі суспільства $i$, на сьогодні залишається однією 3 найефективнішою противагою неминучим кризовим явищам. А, також, залишається досить суттєвим важелем у відродженні сімейності, збільшенні населення, відтворення традицій тощо, бо може впливати на кризове середовище своєю парною стійкістю i, частково, знівельовувати рушійні наслідки кризи. Яким чином ці взаємодії відбуваються і як деформаційні процеси впливають на свідомість жінок раннього віку дорослості, що обумовлюють їх негативний погляд на одруження та амбівалентне ставлення до цього питання винесено в сферу досліджень. Бо. Так само, як зовнішні умови впливають на свідомість людини, так і людина, своїми реакціями, міркуваннями та діями впливає, зворотно, на формування простору навколо неї. В якості таких деформаційних процесів були винесені на розгляд:

- стереотипізація щодо розподілу сімейних обов'язків між жінкою та чоловіком;

- поширення офіційно не оформлених «шлюбних» стосунків, тобто концесуальний шлюб;

- брак знань та навичок щодо існування сім'ї як інституції у відкритому суспільстві; 
- зміна поглядів на правдавні традиції та їх вплив на свідомість i формування новітніх традицій;

- зниження показників кількості одружень та збільшення кількості розлучень;

До того ж, з’являється молодіжна традиція, коли молоді люди починають обирати житття разом, відкладаючи офіційний шлюб «на потім». За статистикою, в Україні на сьогодні близько чверті неодружених молодих людей живуть з партнером/кою. При цьому, багато з тих, хто хоче одружитися, говорить про низький рівень прибутку й освіти, недовіри до партнера, відсутність навичок створювати сімейні «здорові» комунікації, а всі ці, фактори, на їх думку, є необхідною передумовою для створення сім’ї.

Ключові слова. Амбівалентність, соціум, традиції, батьки, батьківська сім'я, шлюб, одруження, психіка, гендер, фемінізм, концесуальний шлюб, період дорослості, амбідентність, фрустрація.

Kukharchuk Natalia Petrivna Postgraduate student of the Department Aviation Psychology National Aviation University, Kiev, 03058, Cosmonaut Komarov Ave., 1, e-mail: nata.organicera@gmail.com, https://orcid.org/0000-0003-4992-0433

\section{THE INFLUENCE OF TRADITIONS AS A SOCIAL FACTOR ON ATTITUDES TOWARD MARRIAGE IN WOMEN IN EARLY ADULITY}

Abstract. The publication highlights how the influence of current trends changes the traditional views and attitudes to long-standing traditions regarding marriage, married life and family and marital relations and how such changes affect the formation of behavior and attitudes of young adult women to marriage in modern times. A family is a community of people who are bound together by mutual rights and responsibilities as spouses, as parents or future parents, by running a joint household, by shared views, or by a common goal for the development of their family. It was created and exists as the primary center of society, endowed with important social functions, has powerful traditions, and occupies an important place in the life of every person. It is a social institution and today, it remains the most stable in the social structure of society and today remains one of the most effective counterbalances to the inevitable crisis. It also remains a significant tool in the revival of the family, population growth, reproduction of traditions, etc., because it can affect the crisis environment with its pair stability and, in part, offset the drivers of the crisis. How these interactions occur and how deformation processes affect the consciousness of young women of adulthood, which causes their negative view of marriage and ambivalent attitude to this issue has been brought into the field of research. For. Just as external conditions affect a person's consciousness, so a person, by his reactions, reasoning and actions, influences, on the contrary, the formation of the space around him. As such deformation processes were submitted for

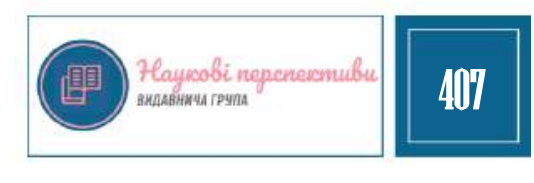


consideration:

- stereotyping about the division of family responsibilities between a woman and a man;

- the spread of not officially formalized "marital" relations, ie concessional marriage;

- lack of knowledge and skills about the existence of the family as an institution in an open society;

- change of views on true traditions and their influence on consciousness and formation of new traditions;

- decrease in the number of marriages and increase in the number of divorces;

In addition, there is a youth tradition where young people begin to choose to live together, postponing a formal marriage. According to statistics, in Ukraine today about a quarter of unmarried young people live with a partner. At the same time, many of those who want to get married say about the low level of income and education, distrust of the partner, lack of skills to create family "healthy" communication, and all these factors, in their opinion, are a necessary prerequisite for starting a family.

Keywords: ambivalence, society, traditions, parents, parental family, marriage, marriage, psyche, gender, feminism, concessional marriage, adulthood, ambition, frustration.

Постановка проблеми. Визначити та показати зв'язок і вплив низки вищевказаних соціальних чинників, які негативно впливають на сприйняття жінками раннього віку дорослості одруження, внаслідок чого у них формується амбівалентне ставлення до цього явища.

Аналіз останніх досліджень і публікацій. Дана проблематика, феномен формування амбівалентності в поглядах людей, віднайшов своє вивчення в роботах i дослідженнях вітчизняного наукового простору, зокрема в дослідження в галузі історичної демографії, тобто дисципліни, яка, як відомо, знаходиться на стику демографії і історії. В процесі роботи розглядалися праці українських істориків і етнографів щодо історії шлюбу і сім’ї у XVII-XVIII століттях - М. Чубатого, А. Пономарьова, а також праці співробітників Демографічного інституту Української Академії наук - Ю.КорчакаЧепурківського, П. Пустохода, М. Трацевського щодо шлюбності населення у другій половині XIX - на початку XX століття. Серед українських демографів наших сучасників слід згадати А. Перковського, який плідно досліджував українську сім'ю XVII-XVIII століття. Однак в цілому сучасна українська демографія не приділяє достатньо уваги історії шлюбу і сім'ї. Тож, ми винесли на розгляд цієї статті в рамках великого дослідження, вплив таких соціальних чинників як традиції та гендерні ролі в сім'ї, як соціальні чинник, що мають прямий вплив на світогляд та психологічний стан жінок раннього віку дорослості щодо ставлення до одруження та як підстав виникнення 
амбівалентних поглядів.

Мета статті. Полягає у розкриття сприйняття жінками раннього віку дорослості економічних чинників як таких, що впливають на формування у них бажання одружитися та їх вплив на стабільність шлюбних відносин.

Виклад основного матеріалу.Тлумачення, значення слова «одруження»: «ОДРУ́ЖЕННЯ, я, сер. Дія за значенням одружити і одружитися» (Словник української мови 2001) [30].

«ОДРу́жУВАТИСя, уюся, уєшся, недок., одРужи́тися, одружу́ся, одру́жишся, док., з ким, на кому і без додатка. Брати шлюб» (Словник української мови 1970-1980)[31].

Доречно згалати, що вчені не дійшли щодо єдиного погляду на період дорослості по віку. Він не завжди чітко розбивається на стадіі, тому що зміни психічних процесів та особистості зумовлені не лише хронологічним віком, а в більшій мірі визначаються особистісними соціальними та культурними факторами. Соціально-економічний статус, міське або сільське середовище, етнічна приналежність, історичні періоди, війни, економічна депресія, тощо впливають на світогляд та поведінку людини.

В нашому емпіричному дослідженні ми обрали найширші межі віку жінок, що відносять до віку ранньої дорослості, а саме від 25 до 45 років, за Е.Еріксоном. I проводили дослідження шляхом анкетування, інтерв'ю, спостереження, тестування.

Під час дослідження було з'ясовано, що важливим чинником для жінки, який формує їі погляди на одруження є загальна когнітивна складова уявлень про жіноче особисте щастя.

I в цій тезі існує, одночасно, два різноспрямовані напрямки бачення, які конфліктують один з одним:

по-перше, це, бажання реалізуватися в соціумі як особистість, отримати соціальне визнання, реалізувати свої власні амбіції через освіту в професії,

по-друге, це багатовікове покликання і природне бажання реалізуватися саме як жінка - одружитися, мати взаємність з чоловіком, мати свою домівку, виховувати дітей тощо.

На сьогодні реалізувати особистісні амбітні професійні плани залежить тільки від дій самої жінки, а от плани щодо одруження і створення сім’ї залежать не лише від самої жінки, а й від партнера також. Суперечності з'являються коли жінці доводиться виконувати (обирати) функції жінки, матері та професіонала одночасно. Спостереження свідчать про те, що чим молодше жінка, тим більше шансів, що між кар'єрою та сім'єю вона вибере сім'ю. Бо модель одночасно подвійної зайнятості може змусити жінку ідентифікувати свої функції, відштовхуючись від традиційної феміної ролі. В умовах сьогодення, вживається словосполучення «феномен подвійної зайнятості», тобто коли жінка працює на роботі, в соціумі, а потім також працює вдома як господиня, жінка, матір. Такі ситуації в суспільстві призводять до поділу жінок

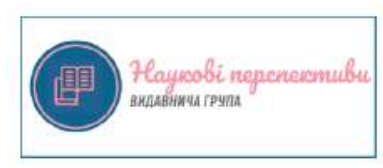


у поглядах. У однієї частини жінок превалює побутовий, сімейний пріоритет, а у інших соціальний, професійний.

Тож ми поставили цілу низку питань щодо розподілу сімейних обов’язків між жінкою та чоловіком;

Твердження «чоловік повинен займатися домашнім господарством на рівні із жінкою» мало такий розподіл поглядів респонденток:

Таблиия. 1

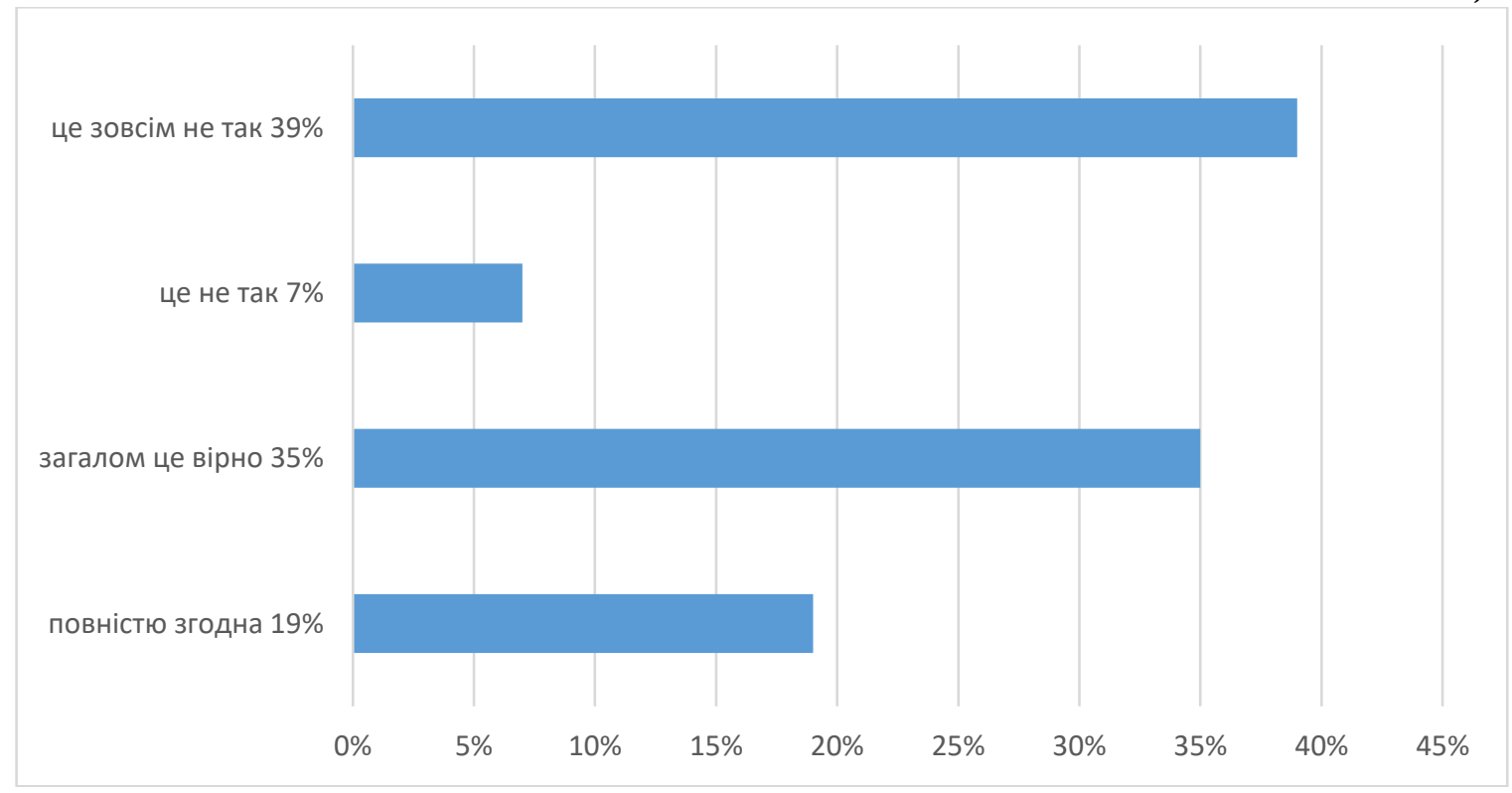

Тобто, з цього питання погляди жінок розділилися майже навпіл: 46\% вважають тезу більш невірною на їх бачення, а 54\% жінок вважають прямо протилежно, тобто що чоловік дійсно повинен розділити з жінкою роботу по домашньому господарству.

А от 3 наступних трьох тез, які випливають 3 першої, вже від 76 до 94 відсотків респонденток вважають, що вклад чоловіка повинен бути на рівні із жіночим, тобто спільним у рівних долях. Бо до спільного ведення господарства відноситься і побут, і виховання дітей і атмосфера сім’ї .

На питання щодо «чоловік повинен вміти обслуговувати себе самостійно, а не покладатися тільки на жінку» погляди розділилися таким чином: 
Таблиия 2

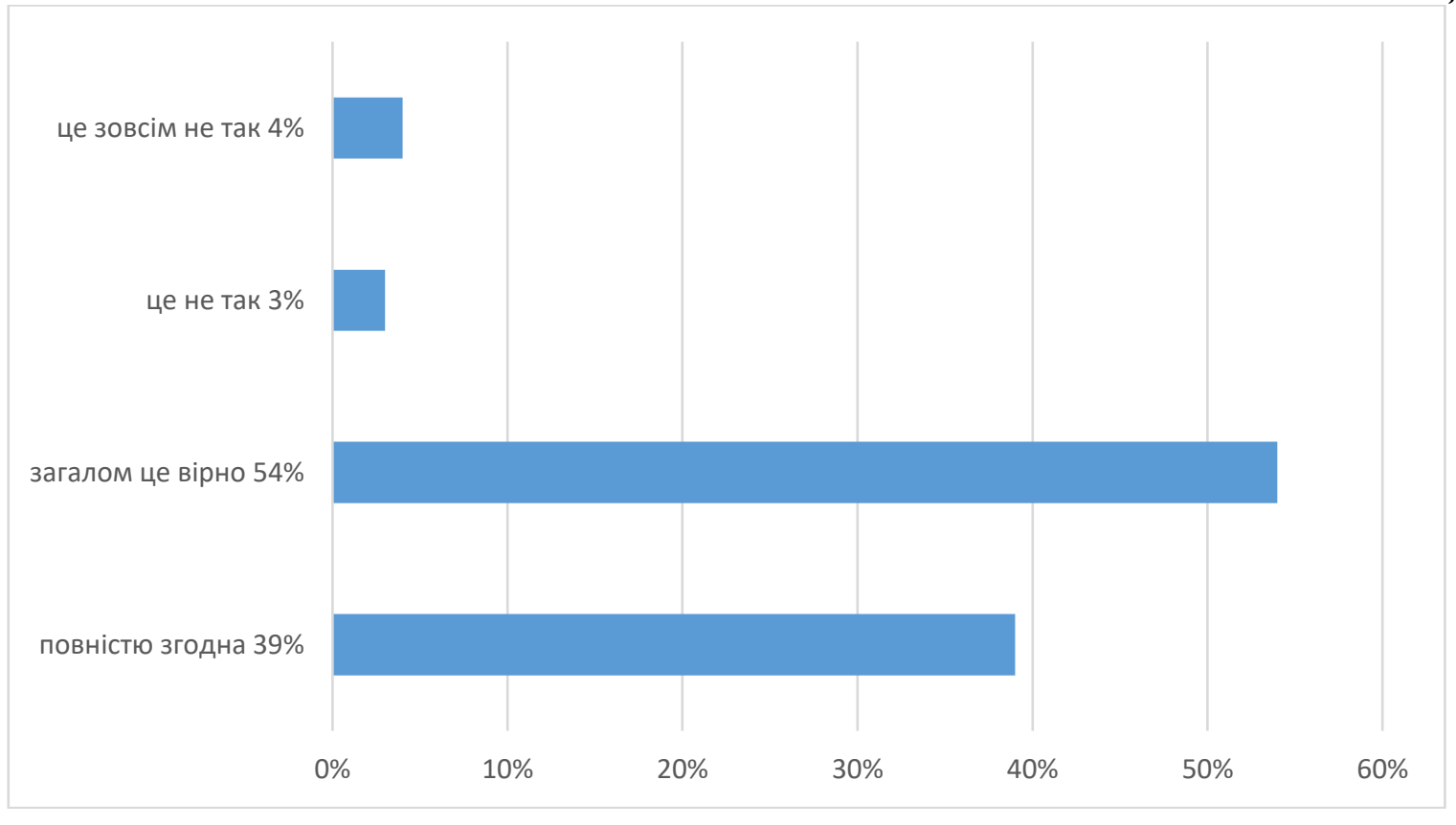

На питання «чоловік повинен займатися дітьми не менше, ніж дружина» респондентки дали такі відповіді:

Таблиия 3

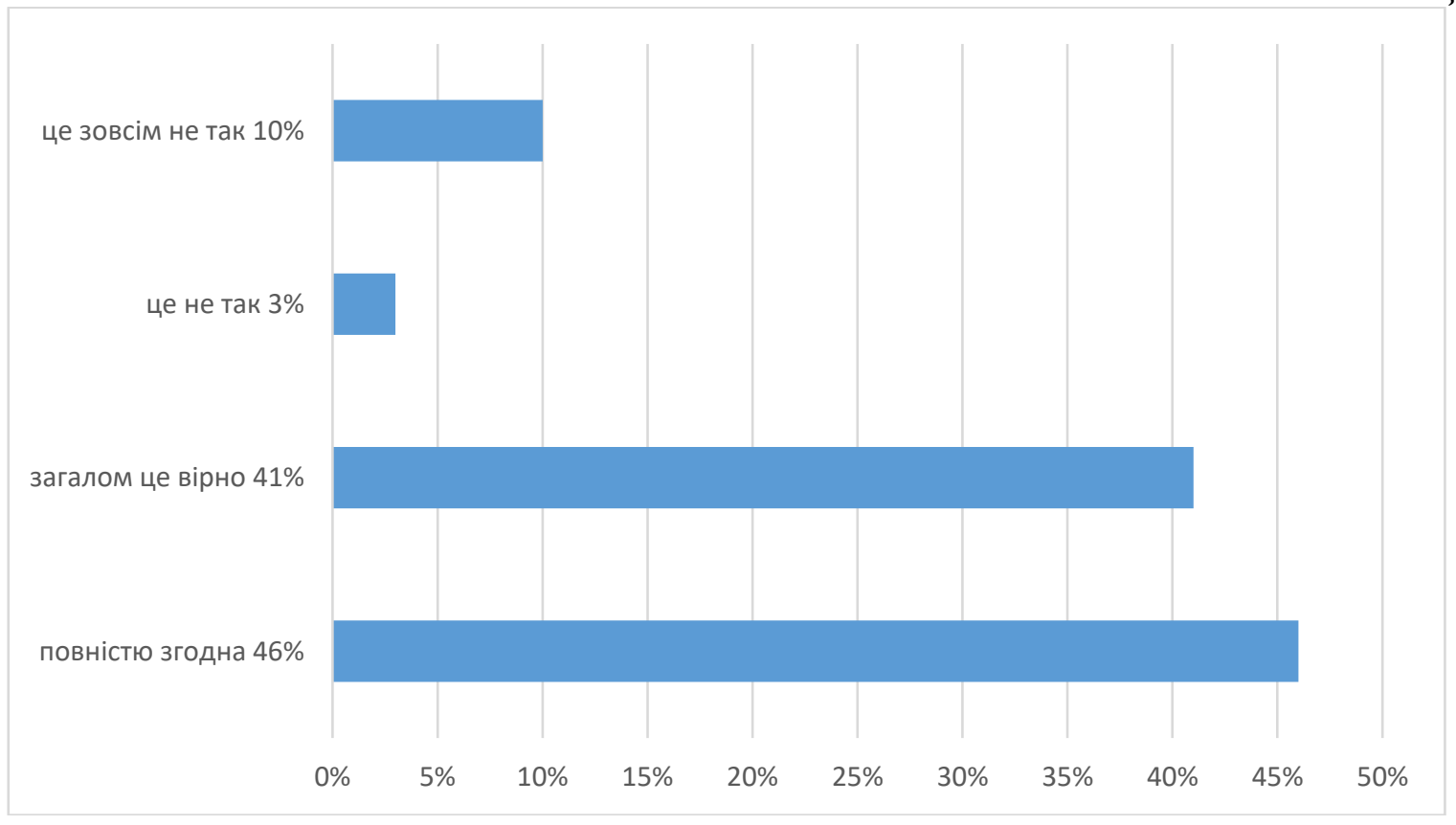

На питання «чоловік повинен створювати в сім'ї теплу атмосферу довіри» думки розподілилися таким чином: 


\section{Таблиия 4}

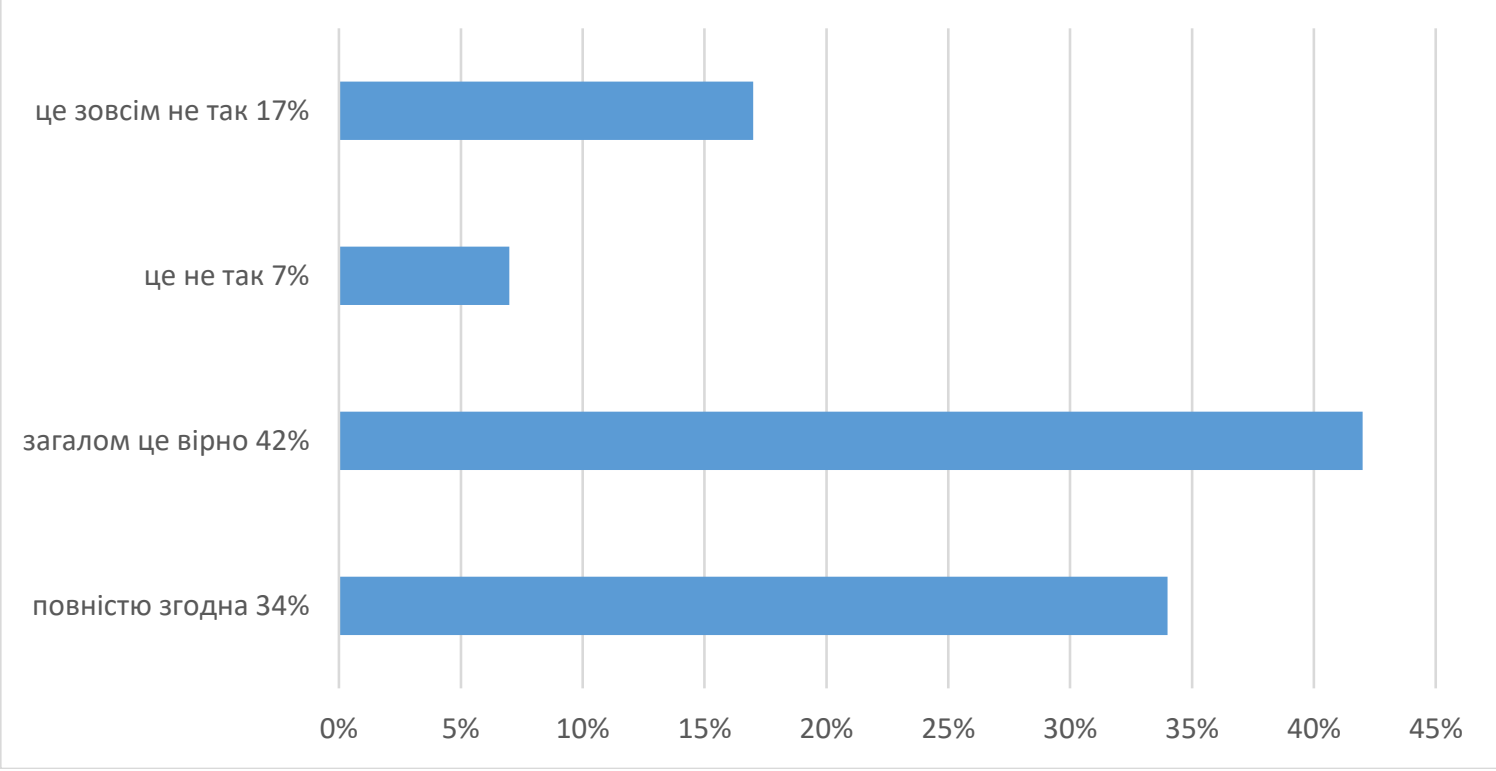

Висновок $з$ цього такий, що коли питання конкретизується, то вони мають дещо інше розуміння і цим пояснюється інший розподіл відповідей. Тому, вважаємо за доцільне висловити думку, що відповіді на перше питання, яке мало загальне формулювання, не відображають дійсне бажання відсотку жінок, щоб чоловік вносив такий же вклад у веденні домашнього господарства як $\mathrm{i}$ сама жінка і мають похибку до 40\%.

3 огляду на викладене вище, існує ймовірність до 40\% коли жінка говорить чоловікові, своєму обранцю, що вона не вважає, що «чоловік повинен займатися домашнім господарством на рівні iз жінкою», а потім, по сегментних питаннях спільного побуту буде очікувати або вимагати від нього рівнозначної участі, наприклад у вихованні дитини - це може бути підгрунтям для суперечок між подружжям та тим самим тригером, який жінка не усвідомлює і який може викликати амбівалентність сприйняття нею дій свого обранця. Дослідження соціально - рольового статусу жінки та чоловіка у сім'ї $\epsilon$ важливим. 3 дослідження вбачається, що на сьогодні «маятник» хитнувся до вирівнювання вкладу кожного з подружжя в створення та укріплення стосунків.

Другий аспект, який ми винесли на розгляд як деформаційний процес розлучення, як у батьківській сім’ так і у власних відносинах.

Проаналізувавши в темі дослідження питання стану одруження /розлучення у респонденток та здійснивши порівняльний аналіз 3 їх батьківської сім'єю на момент проведення досліджень, ми звернули увагу на те, що наші респонденти мали стан: 
Таблиия 5

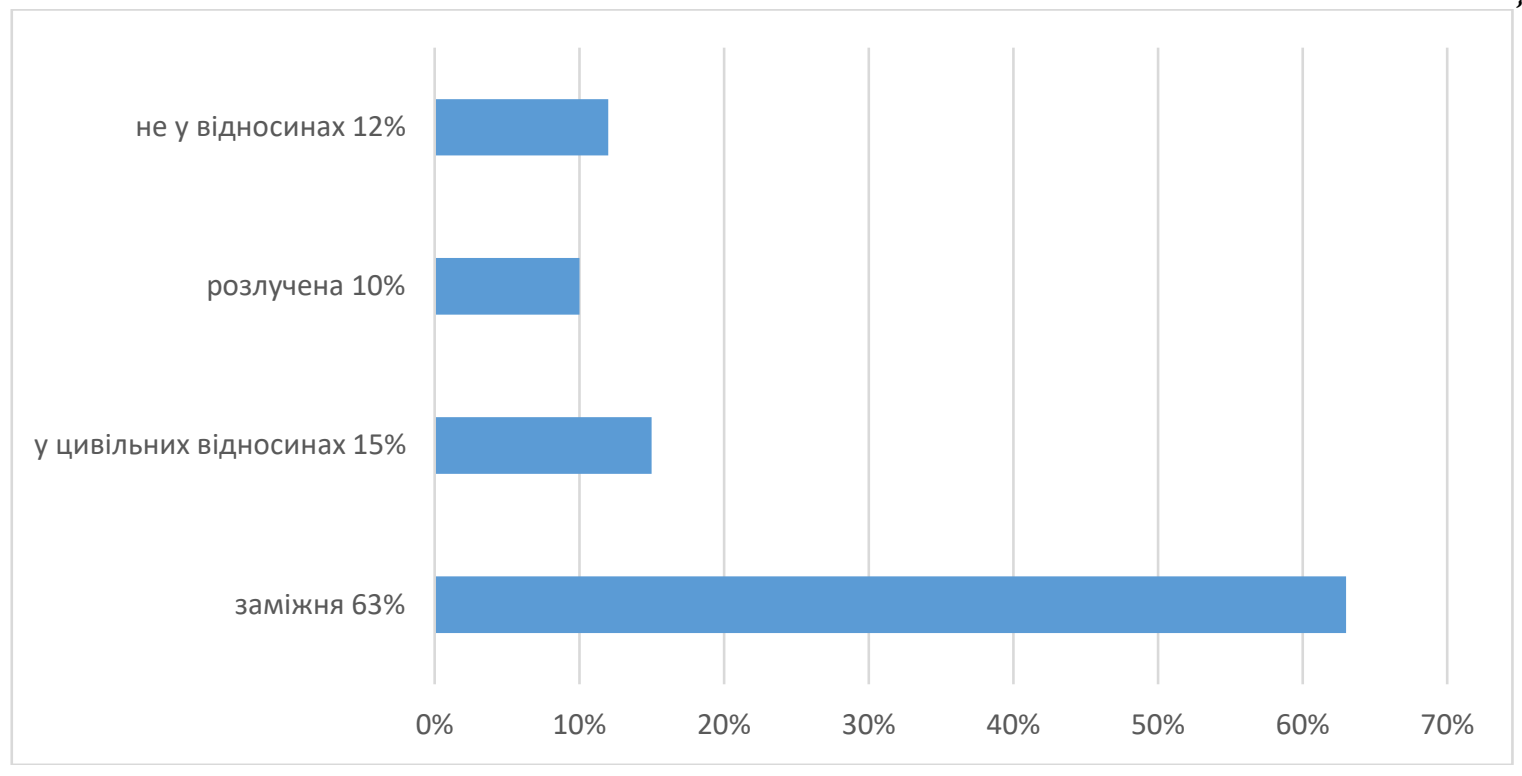

Порівняння з станом батьківської родини свідчить про наступне:

Таблиия 6

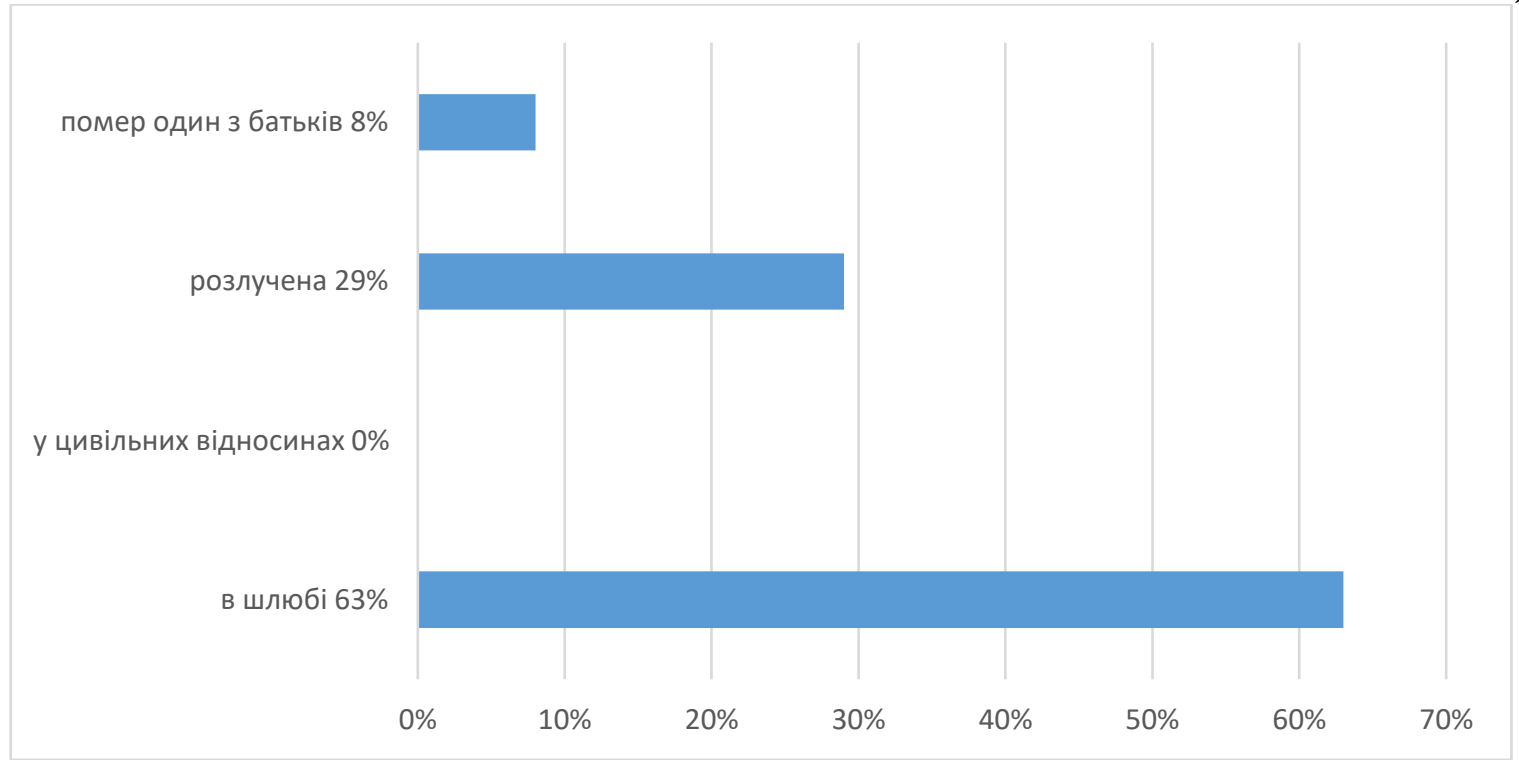

Окремо ми проаналізували такий чинник, як освіта, вища освіта та його вплив на розлучення, або на прийняття рішення не одружуватися.

Загалом $17,8 \%$ респонденток має одну вищу освіту, а 71,2\% респонденток має дві і більше вищих освіти. Ми розглянули вплив освіти опитуваних на стан їх одруження.

Як вбачаємо нижче, наша вибіркова група доводить, перше, що наявність освіти і не одної не заважає шлюбним стосункам, а, по-друге, кількість осіб, що перебувають у офіційних відносинах вище у виборці, де респондентки мали дві i більше вищих освіт. Тож, висловимо припущення, що наявність освіти 
розширює кругозір і впевненість особи в собі, а можливість отримувати додаткову освіту, продовжувати навчання і сталий розвиток говорить про впевненість жінки в собі, в економічній і часовій іï можливості і вмінні будувати відносини з партнером так, щоб іiі заняття не впливали негативно на стан стосунків і не призводили до конфліктів, які породжують розлучення.

Таблиия 7

\section{Таблиця впливу наявності освіти на стан одруження респонденток}

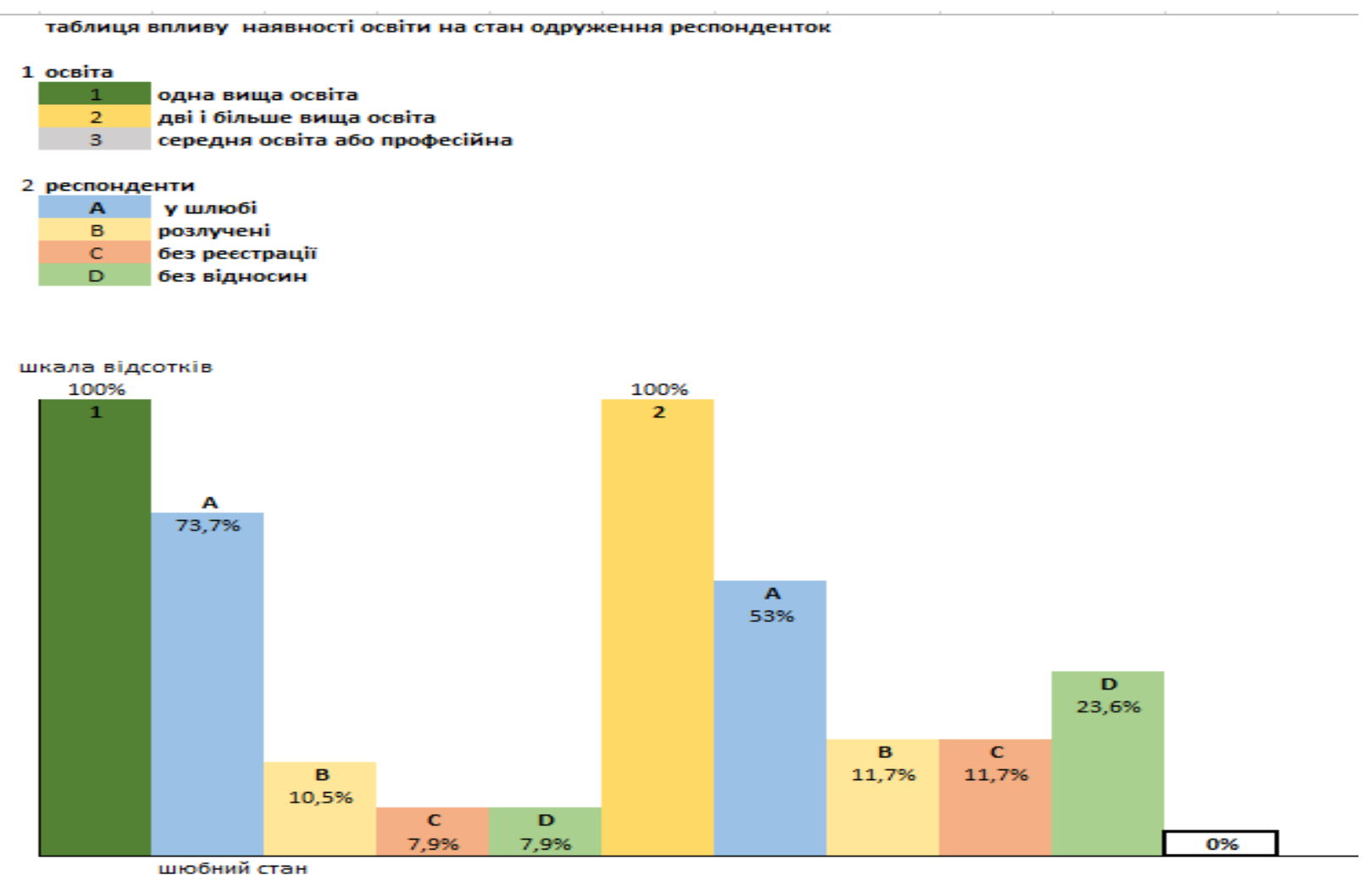

Узагальнюючі ці дані, є підстави висловити наступний висновок:

загальна картина щодо відносин які зареєстровані на тому ж рівні, що й у попереднього покоління. Традиційні цінності поки що зберігаються. Це статистичні дані даної репрезентативної групи людей. Ми не вивчали підстави розлучень, умови зберігання сім’ї або клімат у батьківській родині. Бачимо, що:

по-перше, що зберігається відсоткова група міцних шлюбів і вони всі зареєстровані;

по-друге, наявність вищої освіти не впливає на збільшення показника розлучень або вибору жінки не одружуватися;

по-трете, вибірка даних у покоління жінок раннього віку дорослості проявила ще одну позицію, таку, як відносини без реєстрації, так званий «цивільний або концесійний шлюб».

I це був наступний, третій аспект, який ми винесли на розгляд як деформаційний процес.

Статистика підстав для такого вибору жінки формується з наступного: 
1. жінка звільняє себе від відносин, в яких чоловіка вона повинна обслуговувати;

2. через поширений у суспільстві стереотип "гарної дружини”, яка відповідає за всіх у родині і повинна "встигати все";

3. через невміння реалізувати у відносинах «рівність у різності»;

4. через власне «Я» перед трансформацією в «Ми»;

5. ч через створення не сім'ї, а її ідеальної ілюзії;

Всі ці тези часто обслуговуються тезами «він мене не розуміє», «обіцяв одне, а робить інше», «він/вона не здатний до відносин» тощо, а суть полягає в одній відвертій позиції: я хочу зрозуміти себе та навчитися будувати комунікації без порушень.

У таблиці нижче ми провели порівняльний аналіз впливу шлюбного стану батьківської сім'ї, на сімейний та інший стан респонденток.

Таблиия 8
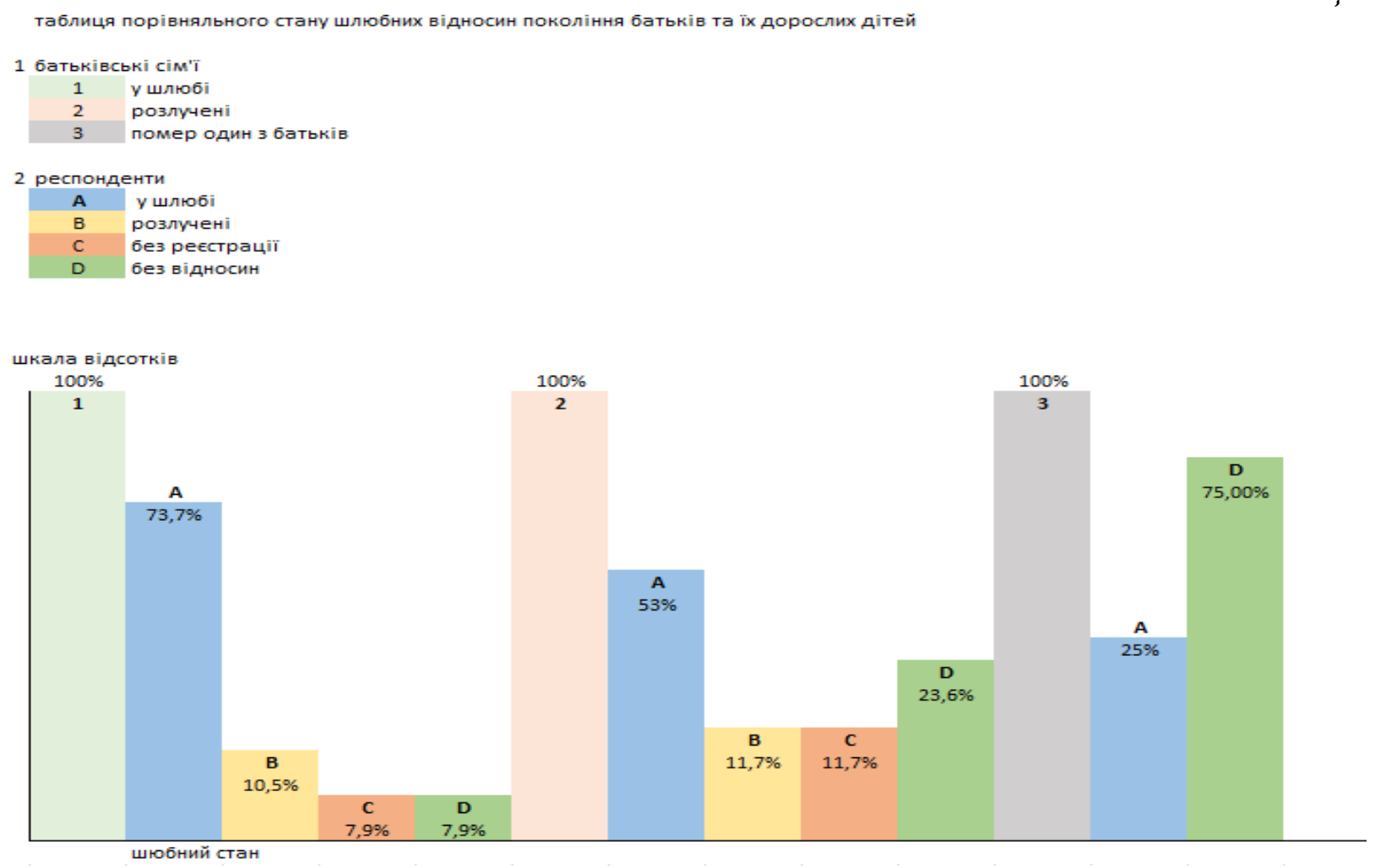

Ця таблиця висвітлює два суттєвих показника:

перший - у батьківських родина які пережили розлучення, відсоток розлучень наступного покоління майже вдвічі більший ніж у порівнянні $з$ тими сім'ями, які перебувають у шлюбі;

друге - всі респондентки, що складають групу «не у відносинах» 3 батьківської родині де є один або двоє померлих батьків;

Четвертий аспект, який ми винесли на розгляд як деформаційний процес - 
зміна поглядів на традиції шлюбу, сім’ї, одруження. «В історичній ретроспективі в первісному суспільстві, провідна роль належала жінці як прародительці роду людського, яка виконувала дітородну функцію. А шлюбні зв'язки були тимчасовими. Рідство визначалося за материнською лінією, у суспільстві існував матріархат. Поступовий розвиток соціально-економічних відносин обумовив перехід до патріархату, який утвердився завдяки монополізації чоловіком приватної власності. На цій основі відбулося формування сімейних відносин, які мали патріархальний характер. Провідна роль як у спільних, так і у родинних стосунках, належала чоловікові. Виникали різні типи сімей 3 їх життєвими циклами, ідеологіями, формувався інститут шлюбу» (Юда Л.А. 2009 с 16) [27].

На сьогодні погляд на сім’ю зрушується «до центру», тобто до рівності прав між чоловіком і жінкою та до рівного вкладу в облаштування сімейного побуту, поглядів і ролі кожного з подружжя.

Розглядаючи бачення жінок функції чоловіка в відносинах не лише тим, що забезпечує матеріальний статок, а й тим, хто впливає на створення обстановки в сім'ї - вбачаємо наступне:

- «чоловік створює теплу обстановку довіри» в взаєминах і в родині мала такий розподіл поглядів:

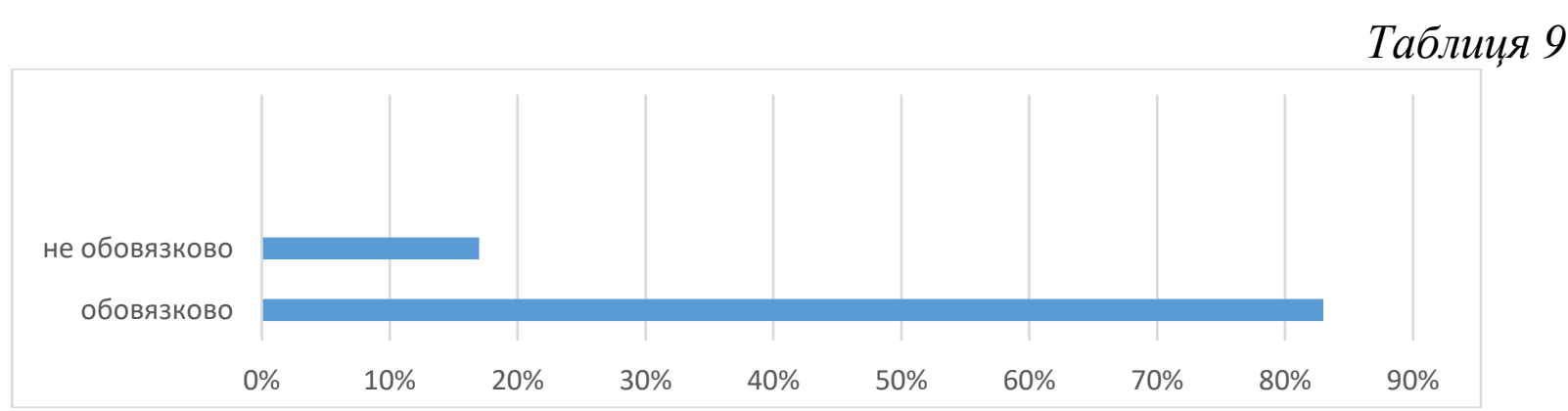

-«чоловік повинен бути носієм таких якостей»

Таблиця 10

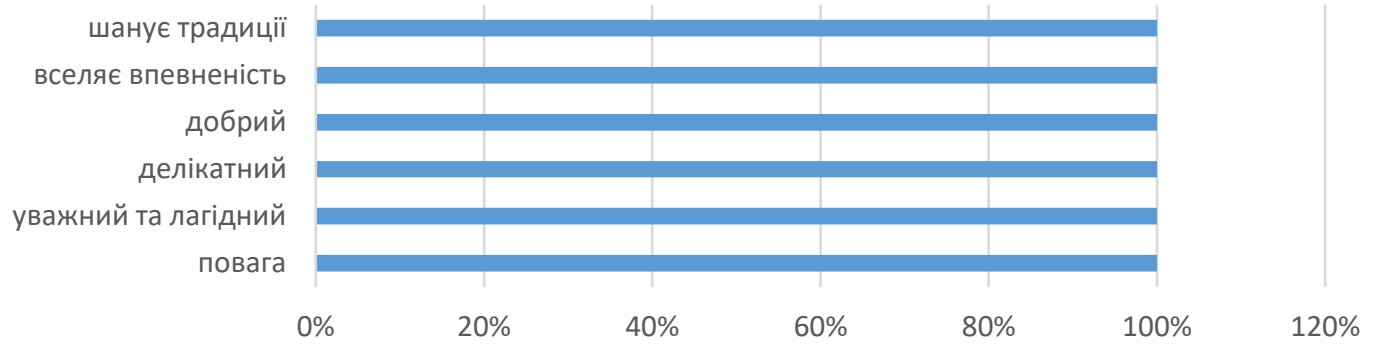

100\% респонденток були однозначні у своєму бажанні бачити ці якості у своєму партнері

Аде наступні дві тези виявили інше бачення щодо такої якості у чоловіка як «повага до думки інших (врахування інтересів інших людей, уникнення 
конфронтації). Відповіді розподілилися таким чином:

Табличя 11

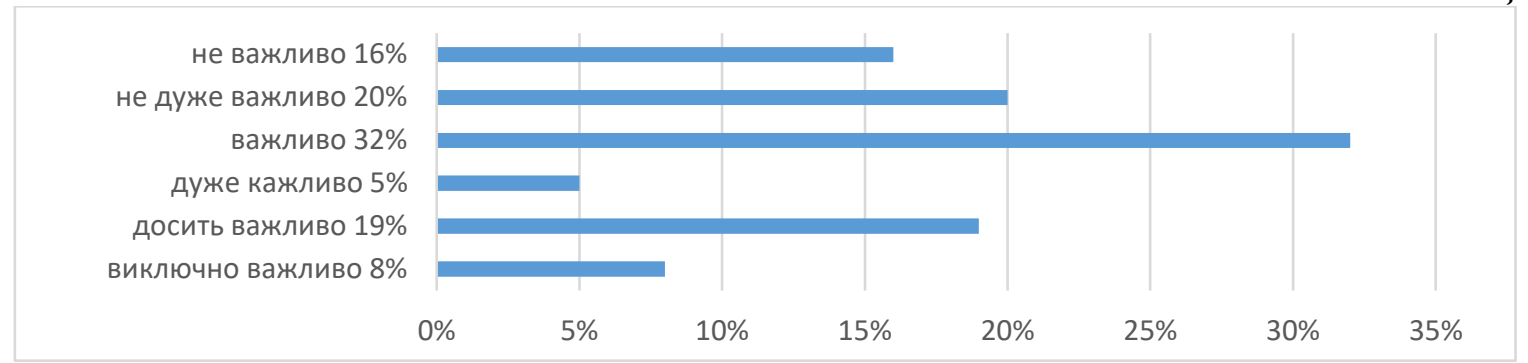

На питання щодо «відкритості чоловіка до чужих думок (терпимість до різних ідей та вірувань)» розподіл бачення такий:

Таблиия 12

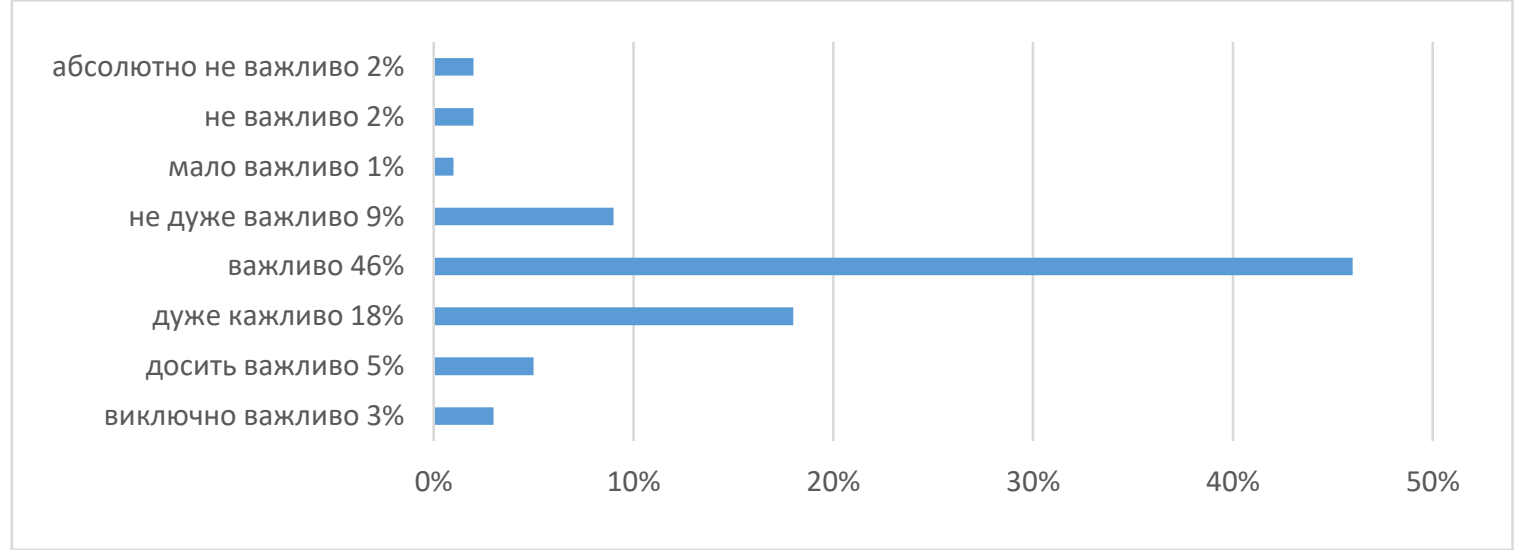

Бачимо, що загалом опитувані поділяються на тих, для кого це в сукупності «важливо», «дуже важливо», «достатньо важливо», «виключно важливо» - 72\% та решта 28\% ті, яким ця якість сукупно «абсолютно неважлива», «не важлива», «мало важлива», «не дуже важлива».

Тож, знову бачимо, що коли питання конкретизуються, а не $\epsilon$ більш узагальненими, відповіді змінюються i, на нашу думку, показують дійсне ставлення жінки до проблематики. Крім цього, така статистика відповідей на останню тезу проявляє відокремлення жінкою себе від частини суспільства (інших), хоча кожен з нас і формує суспільство в цілому і атмосферу його.

Таким чином, ми бачимо, що загалом $36 \%$ опитуваних не вважають важливим у чоловіка в поведінці такого підходу як врахування інтересів інших людей, уникнення конфронтації через повагу до думок інших людей. Це прикро, бо така статистика призводить до того, що жінка, по-перше, не сприймає себе як частину суспільства при взаємо відносинах з чоловіком, можливо, мова йде про бажання виключного ставлення лише до неї. А, подруге, статистика показує, що люди, зазвичай, мають певні поведінкові звички і ці звички розповсюджуються на будь-кого, тобто на любу іншу людину. Тож, 
такі жінки можуть отримати у взаєминах зовсім інший результат, ніж очікують. Подібне можна визнати аспектом афективно-когнітивної сфери амбівалентності особистості, і це є переживання толерантності до суперечливої двоїстості задоволення-незадоволення. В умовах такої амбітендентності накопичується напруга від незадоволення протилежних цінностей та виникає фрустрація (незадоволеність), яку особистість переживає як фрустраційну толерантність.

Подібні «неочікуваності» для жінки провокують незадоволення своїм обранцем, невпевненість у своїх виборах та недовіру до себе, сприяють розвитку амбівалентного ставлення до одруження а також, збільшенню кількості розлучень. Тож, вбачаємо, що розуміння інформаційної суті того чи іншого терміну, та того, що саме певна людина під ним для себе вважає - це можуть бути різні речі. I на цій невідповідності можуть виникати особистісні конфлікти та взаємні непорозуміння.

Всі подібні непорозуміння, або безпідставні очікування впливають на існування сім’ї у відкритому суспільстві.

Це $є$ останній, п’ятий аспект, який ми розглядали як деформаційний процес.

Актуальним на сьогодні $є$ :

- вивчення і зміна стереотипу щодо поведінки і ставлення жінки (дружини) до чоловіка і. так само навпаки, чоловіка до жінки як до повноправних і «рівних у відмінностях» партнерів у сімейних, подружніх стосунків;

- вивчення і зміна стереотипу щодо розподілу обов’язків між чоловіком i дружиною у подружньому житті, побуті.

Висновки. Традиційно шлюбні відносини були необхідні як умова для безпеки, економічної стабільності, законного статусу дітей, та привілеїв у соціумі через статус "заміжня". На сьогоднішній день сім'я перестала бути осередком для виживання або ведення господарства, об'єднання капіталів. Жінка все це може реалізувати й поодинці, так само, як і народжувати та виховувати дітей, не приносячи у жертву ні свій особистий розвиток, ні професійну діяльність. 3 одного боку це добре, бо шлюб позбавився соціальної вимоги бути обов'язковим і обумовлювати роль та положення жінки. 3 іншого боку, ми бачимо, що ні соціальна, професійна чи інша реалізації не може замінити жінці потребу в стосунках з люблячим, надійним, розуміючим иї чоловіком, у кого є любов до дітей і бажання вкладати свої навички, інтелектуальні та матеріальні здобутки в спільний розвиток. Основною загрозою для жінки раннього віку дорослості стосовно того як вона розуміє «одруження» та ставиться до «одруження», є іiі власне розуміння себе і довіра до своїх відчуттів. Це та база, від якої відштовхується їі саморозвиток, розширюється iї світогляд і вона може вистроювати природні, функціональні комунікації без порушення жодних своїх кордонів та поглядів. При такому підході, жінка здатна реально оцінити все, що відбувається навколо неї у соціальному світі, надати цьому правильну оцінку, вжити дії та не боятися 
наслідків, а розуміти їх. Це запорука того, що амбівалентність не буде домінувати в їі психіці.

Секрет ставлення до одруження полягає в банальному розумінні себе, вмінні донести це до партнера, взаєморозуміння і щирий інтерес один до одного.

\section{Jimepamypa:}

1. Амджанін Л. Трансформаційні зміни інституту сім'ї та шлюбних відносин в українському суспільстві: гендерний аналіз. Соціологія: теорія, методи, маркетинг №3. К.:Альманах, 2007. - 75с.

2. Болотіна Н. Б. Соціальне законодавство України. Гендерна експертиза. -К.: Логос, 2001. $-82 \mathrm{c}$.

3. Борисюк О.М. Прохорчук Н.В. Амбівалентність особистості як психологічний феномен. -Л.: Науковий вісник ЛДУВС № 2. 2017. -8 с.

4. Говорун Т., Кікінеджі О. Стать та сексуальність: психологічний ракурс. Навч. Посібник/ Говорун Т., Кікінеджі О. -Т.: Богдан. 1999. -384c.

5. Грицяк Н.В. Гендерний паритет сучасності. -К.: Завуч. 2000.-139 с.

6. Долинська Л.В. Підготовка молоді до сімейного життя (соц.-псих. тренінг) навчально-методичний посібник / Л.В. Долинська, Т.А. Демидова. -К. 2002. -74c.

7. Зелінська Т. Амбівалентність батьківської гендерної ролі. -К.: Початкова школа No3. 2003. -48c.

8. Зелінська Т. Концептуалізація феномену амбівалентності атитюдів особистості. -К.: Психологія і суспільство. 2004. -55с.

9. Зелінська Т. Психологія особистісної амбівалентності в юнацькому віці. -К.: Університетська книга. 2013. -432 с.

10. Кіммел Майкл С. Гендероване суспільство. Пер. з англ. С.Альошкіна. -К.: Сфера, 2003. -494 c.

11. Кравець В.П. Психологія сімейного життя. -Т.: СВС. 1995. -105 с

12. Крючков А.І. Монографія «Деякі проблеми сучасної молодої сім’і» Сучасна українська сім'я: гендерні проблеми та шляхи їх подолання матеріали обласної науковопрактичної конференції 4 лютого 2009 року. -Ч.: ФПО. 2009. -41с.

13. Лукашевич М. Соціологія сім’ї : теорія і практика. -К.: ІПК ДСЗУ. 2012. -186.с

14. Марценюк Т. Гендерна рівність і недискримінація: посібник для експертів i експерток аналітичних центрів. -К.: Відродження. 2014. -65 с.

15. Максименко С.Д. Розвиток психіки в онтогенезі. Том 1 Теоретико-методологічні проблеми генетичної психології. -К.: Форум. 2002 . -319 с.

16. Медіна Т.В. Соціологія сім’ї : навч. посіб.. -Ч.: Наукова література. 2006. -448 с.

17. Оксамитова С. Динаміка сімейного стану та складу сім'ї. Українське суспільство 1994-2004. Моніторинг соціальних змін за ред. В. Ворони, М. Шульги. -К.: Інститут соціології НАН України. 2004. -547 с.

18. Паніна Н. Українське суспільство 1992-1996: соціологічний моніторингю -К.: Інститут соиіологіï НАН України. 2006. -545 с.

19. Помиткіна Л.В.. Злагодух В.В.. Хімченко Н.С., Погорільська Н.І. Психологія сім'ї. Навчальний посібник. -К.:НАУ.2010. -264 с.

20. Рєпнова Т.П. Соціальний патронаж сім'ї - Практична психологія та соціальна робота. № 10. -К.:Компанія "Социс". 2014. -23

21. Рябчук М. Долання амбівалентності. Дихотомія української національної ідентичності - історичні причини та політичні наслідки. -К.: ІПіЕНД ім. І. Ф. Кураса НАН України. 2019. -252с. 
22. Слюсар Л.І. Еволюція шлюбу в Україні: XVII - початок XX сторіччя. -К.: Вісник Інституту демографії та соціальних досліджень ім. М. В. Птухи НАН України. 2011. -11 с.

23. Столлер Роберт. Секс і гендер: про розвиток мужньості і жіночності. Нью-Йорк Таймс. Дом науки. 1968

24. Ткачева В.А. Інститут сім'ї у ретроспективі і сучасності. Філософський альманах: вип.64. -К.: Мультиверсум. 2007. -239 с.

25. Трубавіна І. М. Методи вивчення сім’ї . -К.: УДЦССМ. 2001. -68 с.

26. Уманець Н. Людина та сім'я. Навчальний посібник. -Л,: Львівська політехніка. 2013. -199 c.

27. Юда Л.А. Монографія «Гендерний аналіз українських родинних традицій» Сучасна українська сім'я: гендерні проблеми та шляхи їх подолання матеріали обласної науковопрактичної конференції 4 лютого 2009 рок у. -Ч.:ФПО. $2009 . \quad$-21с

28. Гендерний розвиток у суспільстві: конспекти лекцій. 2-вид. Київ: ПЦ „Фоліант”. 2005. $-351 \mathrm{c}$

29. Демографічна криза в Україні. Проблеми дослідження, витоки, складові, напрями протидії. за ред. В.Стешенко. -Київ: НАН України. 2001. -226 с.

30. Група вчених Інституту мовознавства. Словник української мови: [в 4-х т.]. -Київ: Наукова думка. 2001 - Т.3 - 400с.

31. Словник української мови: [в 11-х т.]. АН УРСР. Інститут мовознавства; за ред. I. К. Білодіда. -Київ: Наукова думка.-Т.8- 1970-1980. -341с:

32. Електронна бібліотека рефератів. Чинники антисуспільної поведінки “біологічні i соціальні. Офіц. сайт: URL: https:/osvita.ua/vnz/reports/psychology/29126/ (дата звернення 09.12.2021)

33. Електронна збірка словників. Тлумачний словник. Офіц. сайт: URL: https://dic.academic.ru/dic.nsf/ruwiki/2489 (дата звернення 11.12.2021)

34. Молода сім'я: проблеми та умови її становлення. За ред. проф. А.Й. Капської. -К.: ДЦССМ. 2003. -184c.

35. Психологічна енциклопедія. Автор-упорядник О.М.Степанов. -Київ: Академвидав. 2006. $-424 \mathrm{c}$

\section{References:}

1. Amjanin L (2007). Institutu sIm'Yi ta shlyubnih vIdnosin v ukraYinskomu suspIlstvI: genderniy analIz. SotsIologIya: teorIya, metodi, marketing TransformatsIynI zmIni No3. [Transformational changes in the institution of family and marital relations in Ukrainiansociety: gender analysis. Sociology: theory, methods, marketing No3.].Kyiv:Almanah [in Ukrainian].

2. Bolotina N.B. (2001). SotsIalne zakonodavstvo UkraYini. [Genderna ekspertiza Social legislation of Ukraine. Gender expertise]. Kyiv: Logos [in Ukrainian].

3. Borisyuk O.M. \& Prokhorchuk N.V. (2017). AmbIvalentnIst osobistostI yak psihologIchniy fenomen. [Personality ambivalence as a psychological phenomenon]. Lviv: Scientific Bulletin [in Ukrainian].

4. Govorun T. \& Kikineji O. (1999). Stat ta seksualnIst: psihologIchniy rakurs. Navch. posIbnik. [Gender and sexuality: a psychological perspective. Teaching manual].Ternopil: Bogdan [in Ukrainian].

5. Gritsyak N.V. (2000). Genderniy paritet suchasnostI. [Gender parity of modernity]. Kyiv: Zavuch [in Ukrainian].

6. Dolynska L.V. \& Demidova T.A. (2002). PIdgotovka molodI do sImeynogo zhittya.(sots.-psih. trenIng) navchalno-metodichniy posIbnik [Preparing young people for family life. (Social and psychological training)]. Kyiv [in Ukrainian].

7. Zelinska T. (2003). AmbIvalentnIst batkIvskoYi gendernoyi roll. [Ambivalence of parental gender role]. Kyiv: Pochatkova shkola. [in Ukrainian]. 
8. Zelinska T. (2004). KontseptualIzatsIya fenomenu ambIvalentnostI atityudIv osobistostI. [Conceptualization of the phenomenon of ambivalence of personality attitudes]. Kyiv: PsihologIya I suspIlstvo. [in Ukrainian].

9. Zelinska T. (2013). PsihologIya osobistIsnoYi ambIvalentnostI v yunatskomu vItsI. [Psychology of personal ambivalence in adolescence]. Kyiv: UnIversitetska kniga. [in Ukrainian].

10. Kimmel Michael S. (2003). Genderovane suspIlstvo. [Gender Society. Per. from English S. Aloshkin]. Kyiv: Sfera, [in Ukrainian].

11. Kravets V.P. (1995). PsihologIya sImeynogo zhittya [Psychology of family life]. Ternopil: SHS. [in Ukrainian].

12. Kryuchkov A.I. (2009). Monograflya «DeyakI problemi suchasnoYi molodoYi sIm'Yi» Suchasna ukraYinska sIm'ya: gendernI problemi ta shlyahi Yih podolannya materIali oblasnoYi naukovopraktichnoYi konferentsIYi 4 lyutogo 2009 roku. [Monograph "Some problems of the modern young family" Modern Ukrainian family: gender issues and ways to overcome them materials of the regional scientific-practical conference on February 4, 2009]. Chernihi: FPO. [in Ukrainian].

13. Lukashevich M. \& Lukashevich M. (2012). SotsIologIya sIm’Yi: teorIya I praktika. [Sociology of the family: theory and practice]. Kyiv: IPK DSZU. [in Ukrainian].

14. Martsenyuk T. (2014). Genderna rIvnIst I nediskrimInatsIya: posIbnik dlya ekspertIv I ekspertok analItichnih tsentrIv [Gender equality and non-discrimination: a guide for experts of think tanks]. Kyiv: Renaissance. [in Ukrainian].

15. Maksimenko S.D. (2002). Rozvitok psihIki v ontogenezI. Tom 1 Teoretiko-metodologIchnI problemi genetichnoi psihologIi [Development of the psyche in ontogenesis. Volume 1 Theoretical and methodological problems of genetic psychology]. Kyiv:Forum. [in Ukrainian].

16. Medina T.V. (2006). SotsIologIya sIm'Yi : navch. posIb. [Sociology of the family: textbook. aid.].Chernivtsi:Naukova IIteratura. [in Ukrainian].

17. Oksamitova S. (2004). DinamIka sImeynogo stanu ta skladu sIm'Yi. UkraYinske suspIlstvo1994-2004. MonItoring sotsIalnih zmIn za red. V. Voroni, M. Shulgi [Dynamics of marital status and family composition. Ukrainian society 1994-2004. Monitoring of social change, ed. V. Voroni, M. Shulgi]. Kyiv: Institut sotsIologii NAN Ukraini. [in Ukrainian].

18. Panina N. (2006). Ukrainske suspIlstvo 1992-1996: sotsIologIchniy monItoringyu [Ukrainian Society 1992-1996: Sociological Monitoring Institute of Sociology of the National Academy of Sciences of Ukraine]. Kyiv. Institut sotsIologii NAN Ukraini. [in Ukrainian].

19. Pomitkina L.V., Zlagodukh V.V., Khimchenko N.S. \& Pogorilska N.I. Psihologiya sIm 'yi. Navchalniy posIbnik. [Family psychology] Kyiv:NAU. [in Ukrainian].

20. Repnova T.P. (2014). SotsIalniy patronazh sIm'i - Praktichna psihologIya ta sotsIalna robota No 10 [Social Patronage of the Family - Practical Psychology and Social Work.No 10]. Kyiv: KompanIya "Sotsis" [in Ukrainian].

21. Ryabchuk M. (2019). Dolannya ambIvalentnostI. DihotomIya ukraYinskoYi natsIonalnoYi IdentichnostI - IstorichnI prichini ta polItichnI naslIdki [Overcoming ambivalence. The dichotomy of Ukrainian national identity - historical causes and political consequences]. Kyiv:IPiEND them. IF Kuras NAS of Ukraine. [in Ukrainian].

22. Slyusar L.I. (2011). EvolyutsIya shlyubu v UkraYinI: XVII - pochatok XX storIchchya [The evolution of marriage in Ukraine: XVII - early XX century]. Kyiv:Bulletin of the Institute of Demography and Social Research. MV Birds of the National Academy of Sciences of Ukraine. [in Ukrainian].

23. Stoller Robert. (1968). Sex and gender: about the development of masculinity and femininity. New York Times, NY:House of Science.

24. Tkacheva V.A. (2007). Institut sIm'Yi u retrospektivI I suchasnostI. [The Institute of the Family in Retrospect and the Present]. Kyiv:Multiverse. [in Ukrainian].

25. Trubavina I.M. (2001). Metodi vivchennya sIm'i [Methods of studying the family]. Kyiv: УДЦССМ. [in Ukrainian]. 
26. Umanets N. (2013) Lyudina ta sIm'ya. Navchalniy posIbnik [Man and family. Tutorial]. Lviv,: LvIvska polItehnIka. [in Ukrainian].

27. Yuda LA.(2009). MonografIya «Genderniy analIz ukraYinskih rodinnih traditsIy» Suchasna ukraYinska sIm'ya: gendernI problemi ta shlyahi Yih podolannya materIali oblasnoYi naukovopraktichnoYi konferentsIYi 4 lyutogo 2009 roku [Monograph "Gender analysis of Ukrainian family traditions" Modern Ukrainian family: gender issues and ways to overcome them materials of the regional scientific-practical conference on February 4, 2009]. Chernihiv: FPO. [in Ukrainian].

28. Genderniy rozvitok $u$ suspIlstvI: konspekti lektsIy [Gender development in society: lecture notes. 2-is a kind]. (2005). Kyiv:PC Foliant. [in Ukrainian].

29. Steshenko V. (Eds.) (2001). DemografIchna kriza v UkraYinI. Problemi doslIdzhennya, vitoki, skladovI, napryami protidIi [Demographic crisis in Ukraine. Research problems, sources, components, directions counteraction]. Kyiv: NAN of Ukraine. [in Ukrainian].

30. Grupa vchenih Institutu movoznavstva. (2001). Slovnik ukrayinskoi movi [Dictionary of the Ukrainian language (Vols. 1-4)]. Kyiv: Naukova dumka. [in Ukrainian].

31. BIlodId I.K. (Ed.) (1970-1980). Slovnik ukrayinskoi movi [Dictionary of the Ukrainian language (Vols. 1-11) USSR]. Kyiv: Naukova dumka. [in Ukrainian].

32. Electronic library of abstracts. Factors of anti-social behavior "biological and social. Officer. Website: URL: https://osvita.ua/vnz/reports/psychology/29126/ (access date 09.12.2021)

33. Electronic collection of dictionaries. Explanatory dictionary. Officer. Website: URL: https://dic.academic.ru/dic.nsf/ruwiki/2489 (accessed 11.12.2021)

34. Kapska A.Y. (Eds.). (2003). Moloda sIm'ya: problemi ta umovi YiYi stanovlennya [Young family: problems and conditions of its formation]. Kyiv: DTSSM. [in Ukrainian].

35. Stepanov O.M. (Eds.). (2006). PsihologIchna entsiklopedIya [Psychological encyclopedia]. Kyiv: Akademvidav. [in Ukrainian]. 